Enikő Tóth

University of Debrecen*

Péter Csatár

University of Debrecen**
UDK 811.511.141'367.626

DOI: 10.4312/linguistica.56.1.281-291

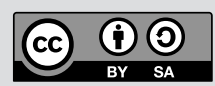

\title{
INDEXICAL DEMONSTRATIVES AND IDENTIFICATIONAL FOCUS IN HUNGARIAN
}

\section{INTRODUCTION}

According to the traditional view, the choice of demonstratives (proximal this vs. distal that) is determined by the relative distance from the speaker. However, this view has been challenged by various authors (Piwek et al. 2008; Enfield 2009; Diessel 2012). For instance, Piwek et al. (2008) suggested that in Dutch acceptability should replace distance as a decisive factor influencing the choice of demonstratives. Recently, Tóth et al. (2014) examined the factors influencing the use of demonstratives in Hungarian, Dutch and English. The results show that the distribution of demonstratives (the number of proximal demonstratives and distal demonstratives) is significantly different in neutral and contrastive contexts when the entities being referred to are close to the speaker. This paper collects further data about the use of Hungarian demonstratives in contrastive contexts via investigating a special subtype of contrastive contexts marked by identificational focus. If the distribution of demonstratives in identificational focus is the same as their distribution in other types of contrastive contexts, then experimental evidence will support the theoretical claim about the contrastive nature of identificational focus.

\section{THE USE OF HUNGARIAN DEMONSTRATIVES}

In Hungarian, there are two types of demonstratives, ez/ezek 'this/these' are proximal, whereas az/azok 'that/those' are distal demonstratives. Regarding their uses, indexical demonstratives are those that are accompanied by a pointing gesture. Levinson (2004) divides indexical uses into two subcategories: non-contrastive (1) and contrastive uses (2-3), as illustrated below.

\footnotetext{
* toth.eniko@arts.unideb.hu

** csatar.peter@arts.unideb.hu
} 
(1) $\mathrm{Ez} \quad$ a dinnye nagyon finom.

this the melon very tasty

DEM.PROX.NOM.SG NOM

'This melon is delicious.'

(2) $A z$

that

a futó nyert, és nem ez.

DEM.DIST.NOM.SG

the runner win

and not this

'That runner has won the race and not this one.'

(3) $\boldsymbol{E} z \boldsymbol{t}$

this

a dinnyét kérem.

the melon want

DEM.PROX.ACC.SG ACC

1SG.PRESENT

'I want this melon.'

Extending Levinson's view and relying on the analyses of Chafe (1994), É. Kiss $(1998,2002)$ and Kaiser (2011), contrastive contexts are defined as follows:

(i) physical context: no conditions;

(ii) epistemic context: the entities are activated in the discourse and they are highly accessible for the participants;

(iii) linguistic context: contrastiveness is explicitly indicated linguistically, for instance by using a coordinating conjunction with a contrastive sense, e.g., but, or by prosodic prominence;

(iv) social context: not relevant.

Contexts that do not satisfy the definition above are labelled as neutral.

\subsection{Hungarian Demonstratives and Identificational Focus}

Identificational focus in Hungarian is marked by stress and the focussed constituent moves into a preverbal position. Moreover, if the verb contains a preverb (see the examples below), it will leave its verb and move into a position that is immediately after the verb. The example in (4) illustrates a neutral sentence (i.e., neutral context in the experiment to be presented), whereas in (5) the NP containing the indexical demonstrative is in identificational focus (i.e., contrastive contexts later on).

(4) Meg-veszem buy

azt

that

PREVERB-1SG.PRES

DEM.DIST.ACC.SG ACC

'I'll buy that book.'

(5) $A z t$

a könyvet veszem meg.

that the book buy

DEM.DIST.ACC.SG

ACC

1SG.PRES PREVERB

'It's that book that I'll buy.' 
There are several theories regarding the syntactic and semantic characteristics of identificational focus. Syntactic theories are concerned with explaining how the movement is triggered, while semantic approaches concentrate on the nature of the exhaustive interpretation of identificational focus. Here only the latter approaches will be described briefly.

The function of Hungarian identificational focus is defined by É. Kiss (1998, 2002) as follows: "The focus represents a proper subset of the set of contextually or situationally given referents for which the predicate phrase can potentially hold; it is identified as the exhaustive subset of this set for which the predicate phrase holds." (É. Kiss 2002: 78)

In general, all theories accept that there is an exhaustive interpretation associated with Hungarian identificational focus. Proponents of the standard analysis (É. Kiss 1998, 2002; Szabolcsi 1981) claim that exhaustivity is a semantic feature, i.e., exhaustivity is part of the truth-conditions of sentences with identificational focus. This view has been challenged recently, for instance by Wedgwood (2005), who claims that exhaustivity is an implicature in a relevance theoretical framework, and by Balogh (2009), who argues that exhaustivity is an obligatory implicature in an inquisitive semantic framework. Empirical studies have also questioned the standard semantic feature theory (for details see Kas and Lukács 2013; Geröcs et al. 2014). In her more recent papers É. Kiss $(2004,2006)$ analyses identificational focus as a specificational predicate and argues that exhaustivity is implied. As it is clear from this brief theoretical overview, there are controversial results regarding the treatment of identificational focus and the status of exhaustivity. For the purposes of the present paper we adopt Balogh's (2009) view, who argues that the exhaustive interpretation is obligatory, provided that the verb contains a preverb and it moves into a postverbal position (Balogh 2009: 139).

Furthermore, É. Kiss (1998) also argues that Hungarian identificational focus can be [ \pm contrastive]. More specifically, it is [+contrastive] "if it operates on a closed set of entities whose members are known to the participants of the discourse. [...] In this case, the identification of a subset of the given set also identifies the contrasting complementary subset" (É. Kiss 1998: 267). The study reported here is aimed at investigating the behaviour of indexical demonstratives in identificational focus and to see whether empirical data can also support this view.

\section{THE EXPERIMENT}

The aim of our experiment is twofold. On the one hand, it wants to reinforce the role of distance in neutral contexts with a different method. On the other hand, the second hypothesis tests whether utterances with distal demonstratives in identificational focus receive higher ratings than utterances with indexical demonstratives in neutral non-focus position. If the findings support the second hypothesis, then empirical evidence will be provided in favour of the claim that identificational focus is a syntactically marked subtype of contrastive contexts. 


\subsection{Materials and Methods}

To explore the hypotheses above we constructed an online questionnaire, which included both neutral and contrastive contexts. In order to ensure maximum reliability of our test we created rich contexts (Meibauer 2012). The task of the participants was to evaluate the acceptability of a reply to a question with respect to a context represented by a picture on a four-point Likert scale (forced choice method). In the picture Lego DUPLO figures displayed a zoo scenario. For the sake of the distance hypothesis, the participants of the mini-dialogue (including the speaker) also appeared in the picture, and a pointing gesture accompanying the use of a certain demonstrative was emphasized in two different ways: (i) it was explicitly mentioned in the dialogue; (ii) the Lego figure depicting the speaker also used a pointing gesture. The location of the referred entities was also clear from the context (all entities being referred to were close to the speaker).

Figure 1: A -contrastive, + proximal test item

Az új gondozót körbevezetik az állatkertben.

A jegesmedvéknél az új gondozó megkérdezi:

- Mit csináltál az előbb a medvéknél?

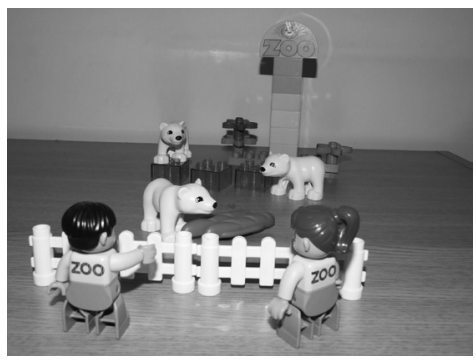

- Ezt a jegesmedvét (rámutat) odacsaltam a száraz kenyérhez.

- 1 teljesen elfogadhatatlan

- 2 kevésbé elfogadhatatlan

○ 3 kevésbé elfogadható

○ 4 teljesen elfogadható
"The new zoo tender is being shown round in the zoo. He/she asks at the polar bear zone:"

"What have you been doing at the polar bears?"

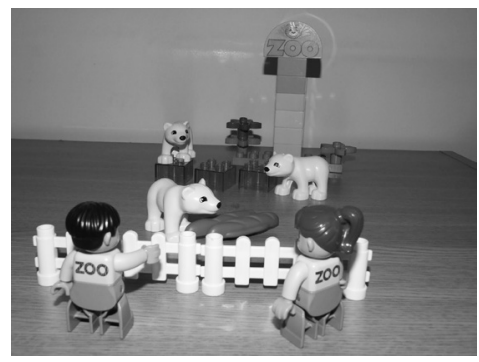

"I have lured this bear (pointing to the bear) to the dry baguette."

- 1 totally unacceptable

- 2 slightly unacceptable

○ 3 slightly acceptable

○ 4 totally acceptable

Moreover, in contrastive contexts the exhaustive interpretation was also prompted with the help of a supportive stimulus which highlighted the difference between the elements identified by the focus and those of the complementary set. In Figure 2 the bandage on the giraffe's leg helps to pick out the entity being referred to. 
Figure 2: A +contrastive, -proximal test item

A két gondozó délután az állatorvoshoz készül a zsiráfokkal.

- Melyik zsiráfot visszük el délután

az állatorvoshoz?

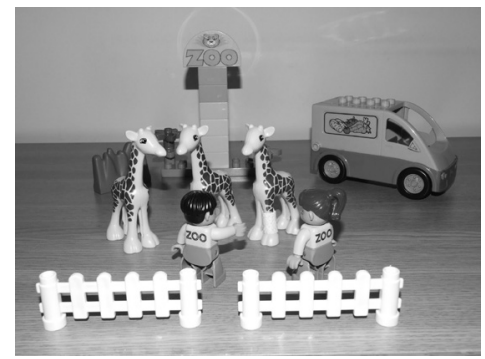

- Azt a zsiráfot (rámutat) visszük el.

$\circ 1$ teljesen elfogadhatatlan

○ 2 kevésbé elfogadhatatlan

○ 3 kevésbé elfogadható

$\circ 4$ teljesen elfogadható
The two zoo tenders are going to take the giraffes to the vet in the afternoon.

"Which giraffe are we taking to the vet in the afternoon?"

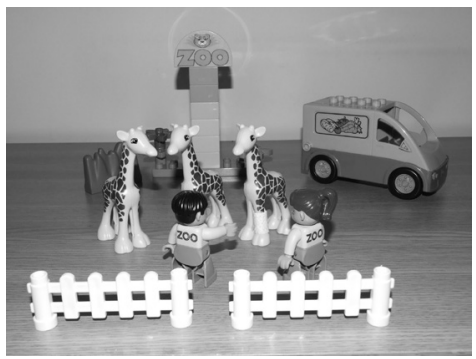

"It's that giraffe (pointing to the giraffe) that we are taking."

$\circ 1$ totally unacceptable

$\circ 2$ slightly unacceptable

$\circ 3$ slightly acceptable

$\circ 4$ totally acceptable

We used a $2 \times 2$ within-subjects design, with the factors ( \pm contrastive and \pm proximal). For instance, the test item in Figure 2 represents a (+contrastive, - -proximal) item. The test included 4 items in each condition and 8 filler contexts. The items were presented in a pre-set random order which was the same for each participant. In each of the test items preverb-verb constructions were used, and identificational focus was marked explicitly by moving the preverb into a postverbal position,

36 participants, all native speakers and students at the University of Debrecen, took part in the experiment. Their average age was 22 years. The participants did not know about the purpose of the experiment.

\subsection{Results and Discussion}

To test the first hypothesis (the role of distance in neutral contexts) we compared (-contrastive, \pm proximal) conditions using the sign test. As expected, there was a significant difference between the ratings of utterances ( $\operatorname{sign}$ test, $\mathrm{z}=-2.00, \mathrm{p}<0.05$ ), i.e., utterances with proximal demonstratives were preferred when referring to entities that were close to the speaker (see Table 1 and Table 2, Figure 3). 
Table 1: Distribution of ratings in the -contrastive, + proximal condition

\begin{tabular}{|l|l|l|}
\hline Ratings & Frequency & Relative frequency (\%) \\
\hline 1 & 17 & $12 \%$ \\
\hline 2 & 22 & $15 \%$ \\
\hline 3 & 41 & $28 \%$ \\
\hline 4 & 64 & $45 \%$ \\
\hline Total & 144 & $100 \%$ \\
\hline
\end{tabular}

Table 2: Distribution of ratings in the -contrastive, -proximal condition

\begin{tabular}{|l|l|l|}
\hline Ratings & Frequency & Relative frequency (\%) \\
\hline 1 & 21 & $15 \%$ \\
\hline 2 & 30 & $21 \%$ \\
\hline 3 & 41 & $28 \%$ \\
\hline 4 & 52 & $36 \%$ \\
\hline Total & 144 & $100 \%$ \\
\hline
\end{tabular}

Hence, as Figure 3 shows, the results reinforced the role of distance: native speakers preferred indexical proximal demonstratives referring to entities that were close to the speaker (cf. Tóth et al. 2014). Coventry et al. (2008) and Luz and Van der Sluis (2011) drew similar conclusions for English, and English, Dutch and Portuguese, respectively. From a methodological point of view, the present results provide converging evidence for the crucial role of distance in neutral contexts.

Figure 3: Relative frequency of ratings in the -contrastive, \pm proximal conditions

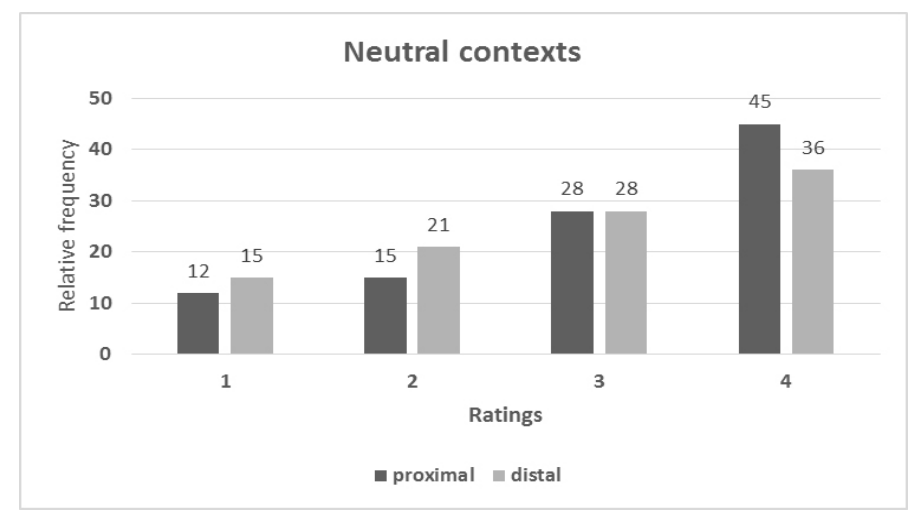


To test the second hypothesis (neutral vs. contrastive contexts) we used the Friedman test, which yielded a significant result across the four conditions $\left(\left(\chi^{2}(3)=21.85\right.\right.$, $\mathrm{p}<0.01$ ). Post-hoc tests (Wilcoxon signed rank tests) detected a significant difference (using a Bonferroni-adjusted significance level) between the acceptability ratings of (-proximal) sentences in contrastive and neutral contexts $(\mathrm{z}=-4.25, \mathrm{p}<0.01)$, i.e., in contrastive contexts, which have been marked by identificational focus, distal demonstratives were judged to be more acceptable than in neutral contexts (see Table 3 and Table 4, Figure 4). It also has to be noted here that from a descriptive statistical perspective this condition was the only one when the modus, i.e., the most frequently selected value, was the highest one, 4 . This means that participants found the utterances with distal demonstratives in identificational focus the most acceptable.

Table 3: Distribution of ratings in the -contrastive, -proximal condition

\begin{tabular}{|l|l|l|}
\hline Ratings & Frequency & Relative frequency (\%) \\
\hline 1 & 21 & $15 \%$ \\
\hline 2 & 30 & $21 \%$ \\
\hline 3 & 41 & $28 \%$ \\
\hline 4 & 52 & $36 \%$ \\
\hline Total & 144 & $100 \%$ \\
\hline
\end{tabular}

Table 4: Distribution of ratings in the + contrastive, -proximal condition

\begin{tabular}{|l|l|l|}
\hline Ratings & Frequency & Relative frequency (\%) \\
\hline 1 & 9 & $6 \%$ \\
\hline 2 & 18 & $12 \%$ \\
\hline 3 & 34 & $24 \%$ \\
\hline 4 & 83 & $58 \%$ \\
\hline Total & 144 & $100 \%$ \\
\hline
\end{tabular}

There is no significant difference between the ratings of (+proximal) utterances in neutral and contrastive contexts. Since the entities being referred to were always close to the speaker, the results are in line with the traditional approach; we expected high ratings in both types of context.

Similarly, there is no significant difference between the ratings of (+contrastive) utterances containing proximal and distal demonstratives in identificational focus. This suggests that in contrastive contexts not only distal demonstratives, but also proximal demonstratives are acceptable, supposing that the entity being referred to is close to the speaker. If only distal demonstratives could be used in contrastive contexts, a significant difference should have been found between (+contrastive) and ( \pm proximal) 
Figure 4: Relative frequency of ratings in the \pm contrastive, -proximal conditions

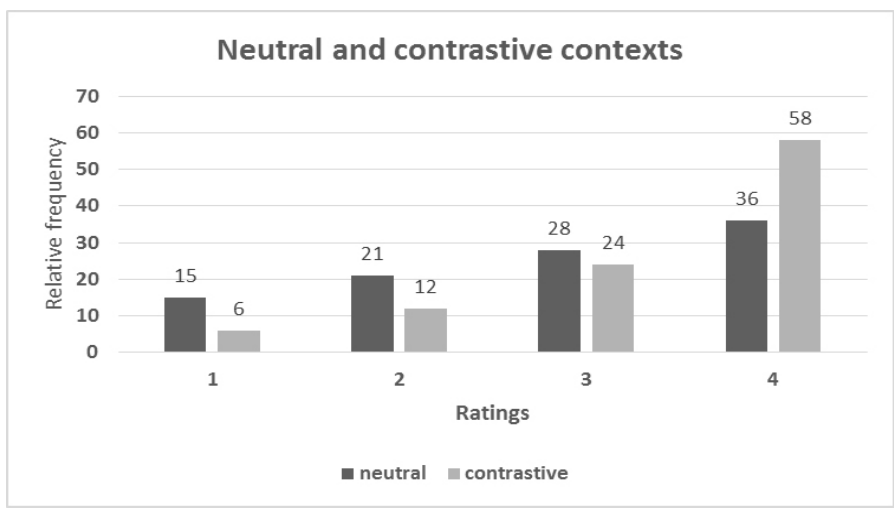

conditions. At the same time it has been proved again that distance on its own cannot explain the use of indexical demonstratives in contrastive contexts. The results above are in accordance with Levinson's (2000) view, who argues that demonstratives in English form a Q-contrast <this, that>, which means that the use of this has to satisfy the criterion of proximity, while the use of that is not restricted in this sense. "This predicts that that has a wide distribution, potentially overlapping with this, as indeed seems to be the case" (Levinson 2000: 94). Our results support the same view regarding the use of Hungarian indexical demonstratives.

\section{CONCLUSION}

To conclude, first, the results provide converging evidence and reinforce that distance plays a crucial role in neutral contexts (when the entities being referred to are close to the speaker). Second, utterances with distal demonstratives in identificational focus received significantly higher ratings. Tóth et al. (2014) also showed that distal demonstratives in contrastive contexts are preferred to proximal demonstratives. Therefore, the theoretical claim that identificational focus forms a subtype of contrastive contexts has been reinforced by the results presented above. More specifically, our findings provide empirical evidence in favour of É. Kiss's (1998) theory about the contrastive nature of identificational focus, at least under the condition that identificational focus is explicitly marked by moving the preverb to a postverbal position.

\section{Acknowledgements}

This research was supported by the National Research, Development and Innovation Office (NKFIH), grant No. K 111918. 


\section{References}

BALOGH, Kata (2009) Theme with variations: a context-based analysis of focus. Amsterdam: ILLC Dissertation Series.

CHAFE, Wallace (1994) Discourse, consciousness, and time: the flow and displacement of conscious experience in speaking and writing. Chicago: University of Chicago Press.

COVENTRY, Kenny R./Berenice VALDÉS/Alejandro CASTILLO/Pedro GUIJARRO-FUENTES (2008) "Language within your reach: near-far perceptual space and spatial demonstratives." Cognition 108, 889-895.

DIESSEL, Holger (2012) Deixis and demonstratives. In: C. Maienborn/K. von Heusinger/P. Portner (eds), 2407-2431.

EMONDS, Joseph/Markéta JANEBOVÁ (eds) (2014) Language use and linguistic structure. Proceedings of the Olomouc Linguistics Colloquium 2013. Olomouc: Palacky University.

ENFIELD, Nick J. (2009) The anatomy of meaning. Speech, gesture, and composite utterances. Cambridge: Cambridge University Press.

É. KISS, Katalin (1998) "Informational focus vs. identification focus." Language 74/2, 245-273.

É. KISS, Katalin (2002) The syntax of Hungarian. Cambridge: Cambridge University Press.

É. KISS, Katalin (2004) Identificational focus and informational focus revisited. In: L. Hunyadi/Gy. Rákosi/E. Tóth (eds), 59-72.

É. KISS, Katalin (2006) Focussing as predication. In: V. Molnár/S. Winkler (eds), 169-196.

FINKBEINER, Rita/Jörg MEIBAUER/Petra B. SCHUMACHER (eds) (2012) What is a context? Linguistic approaches and challenges. Amsterdam: John Benjamins.

GARDENT, Claire/Kristina STRIEGNITZ (eds) (2011) Proceedings of the 13th European workshop on natural language generation. Stroudsburg (PA): Association for Computational Linguistics.

GERŐCS, Mátyás/Anna BABARCZY/Balázs SURÁNYI (2014) Exhaustivity in focus: experimental evidence from Hungarian. In: J. Emonds/M. Janebová (eds), 181-194.

HORN, Laurence R./Gregory WARD (eds) (2004) The handbook of pragmatics. Oxford: Blackwell.

HUNYADI, László/György RÁKOSI/Enikő TÓTH (eds) (2004) Proceedings of the $8^{\text {th }}$ symposium on logic and language. Debrecen: University of Debrecen.

KAISER, Elsi (2011) "Salience and contrast effects in reference resolution: The interpretation of Dutch pronouns and demonstratives." Language and Cognitive Processes 26/10, 1587-1624.

KAS, Bence/Ágnes LUKÁCS (2013) "Focus sensitivity in Hungarian adults and children." Acta Linguistica Hungarica 60/2, 217-245.

LEVINSON, Stephen C. (2000) Presumptive meanings: the theory of generalized conversational implicature. Cambridge (MA): MIT Press. 
LEVINSON, Stephen C. (2004) Deixis and pragmatics. In: L. R. Horn/G. Ward (eds), 97-121.

LUZ, Saturnino/Ielka VAN DER SLUIS 2011. Production of demonstratives in Dutch, English and Portuguese dialogues. In: C. Gardent/K. Striegnitz (eds), 181-186.

MAIENBORN, Claudia/Klaus VON HEUSINGER/Paul PORTNER (eds) (2012) Semantics. An international handbook of natural language meaning. Berlin: Mouton de Gruyter.

MEIBAUER, Jörg (2012) What is a context? Theoretical and empirical evidence. In: R. Finkbeiner/J. Meibauer and P. B. Schumacher (eds), 9-32.

MOLNÁR, Valéria/Susanne WINKLER (eds) (2006) The architecture of focus. Berlin: Mouton de Gruyter.

PIWEK, Paul/Robbert-Jan BEUN/Anita CREMERS. (2008) "“Proximal' and 'distal' in language and cognition: evidence from deictic demonstratives in Dutch." Journal of Pragmatics 40, 694-718.

SZABOLCSI, Anna (1981) "Compositionality in focus." Folia Linguistica 15, $141-161$.

TÓTH, Enikő/Péter CSATÁR/Arina BANGA (2014) Exploring Hungarian and Dutch gestural demonstratives. In: L. Veselovská/M. Janebová (eds), 607-625.

VESELOVSKÁ Ludmila/Markéta JANEBOVÁ (eds) (2014) Complex visibles out there. Proceedings of the Olomouc Linguistics Colloquium 2014: language use and linguistic structure. Olomouc: Palacky University.

WEDGWOOD, Daniel (2005) Shifting the focus. From static structures to dynamics of interpretation. Amsterdam: Elsevier.

\section{Summary \\ INDEXICAL DEMONSTRATIVES AND IDENTIFICATIONAL FOCUS IN HUNGARIAN}

This paper presents the results of an experiment regarding the use of Hungarian indexical demonstratives where it is shown that the use of indexicals depends on the nature of the context. More specifically, the use of indexical demonstratives is explored in neutral contexts and in a subtype of contrastive contexts, where contrastiveness is indicated by Hungarian identificational focus. On the one hand, the results reinforce our previous findings that distance is a crucial factor in neutral contexts. On the other hand, it is revealed that utterances with distal demonstratives in identificational focus receive higher ratings on a Likert-scale than utterances with distal demonstratives in a neutral (non-focus) position. These results provide evidence in favour of the contrastive nature of identificational focus in Hungarian, at least under the condition that identificational focus is explicitly marked by moving the preverb to a postverbal position.

Keywords: experimental pragmatics, identificational focus, indexical demonstratives 


\section{Povzetek \\ INDEKSIALNI KAZALNI ZAIMKI IN IDENTIFIKACIJSKI FOKUS V MADŽARŠČINI}

$\mathrm{V}$ članku predstavimo rezultate eksperimenta o indeksialnih kazalnih zaimkih $\mathrm{v}$ madžarščini, ki pokaže, da je raba indeksialnih zaimkov odvisna od narave konteksta. Rabo indeksialnih kazalnih zaimkov smo preverili v nevtralnih kontekstih in v podtipu kontrastivnih kontekstov, kjer je kontrastivnost izražena s pomočjo madžarskega identifikacijskega fokusa. Rezultati na eni strani potrjujejo naša predhodna dognanja, da je oddaljenost ključni faktor v nevtralnih kontekstih. Na drugi strani je iz rezultatov razvidno, da so izreke $z$ distalnimi kazalnimi zaimki v identifikacijskem fokusu na Likertovi lestvici uvrščene višje kakor izreke z distalnimi kazalnimi zaimki v nevtralnem (nefokusnem) položaju. Rezultati kažejo na kontrastivno naravo identifikacijskega fokusa v madžarščini - vsaj pod pogojem, da je identifikacijski fokus eksplicitno označen $\mathrm{s}$ premikom iz predglagolskega v zaglagolski položaj.

Ključne besede: eksperimentalna pragmatika, identifikacijski fokus, indeksialni kazalni zaimki 